\title{
Objective Observations of Read Aloud and Problem Solving Activities with Eyes' Movements
}

\author{
Kyota Aoki \\ Utsunomiya University \\ 7-1-2 Yoto, Utsunomiya \\ Tochigi, JAPAN \\ kyota@is.utsunomiya-u.ac.jp
}

\author{
Shinjiro Murayama \\ Tsukuba University \\ 3-27-6 mejirodai, bunkyoku \\ Tokyo, JAPAN \\ cjc42970@ams.odn.ne.jp
}

\author{
Kohji Harada \\ Utsunomiya University \\ 350, Minemachi, Utsunomiya \\ Tochigi, JAPAN \\ kharada@utsunomiya-u.ac.jp
}

\begin{abstract}
Teachers observe the activities of pupils, and know the types and features of them. However, the observations must be subjective. It is difficult to generalize the knowledge of a teacher. This paper proposes a method to make subjective and quantative observations of pupils about their reading aloud and problem solving activities, the implementation of the method, and the observation results of the implemented reading activity observation system. About read aloud activities and the question answering activities, the implementation observes the timing of key operations and the process of gazing positions. To measure the reading ability, the text read and the questions to measure the level of understanding are prepared. The prepared text and questions are targeted to the third year of Japanese primary school. In the third year of a primary school, reading difficulties are manifested. The implementation generates many kinds of easy-to understand reports. The knowledge acquired from the observations are easy to generalize. This paper shows the method, the implementation, and the observation results.
\end{abstract}

\section{CCS Concepts}

- Applied computing $\rightarrow$ Education $\rightarrow$ Computer-assisted instruction.

\section{Keywords}

Reading Activity; Understanding Texts; Eyes’ Movements.

\section{INTRODUCTION}

Teachers observe the activities of pupils, and know the types and the features of them. Teachers teach the pupils based on the knowledge. However, the observations must be subjective and non-quantitative. These types of knowledge are difficult to generalize.

Reading is one of important parts of human activities. Reading ability is one major theme in education. Reading ability is a base to learn many subjects.

In Japan, if a pupil shows two years' delay of reading ability, the pupil is regarded as to have a reading difficulty. Some Japanese normal public elementary schools have about $20 \%$ of pupils with

Permission to make digital or hard copies of all or part of this work for personal or classroom use is granted without fee provided that copies are not made or distributed for profit or commercial advantage and that copies bear this notice and the full citation on the first page. To copy otherwise, or republish, to post on servers or to redistribute to lists, requires prior specific permission and/or a fee. Request permissions from Permissions@acm.org.

ICEEL 2018, November 5-7, 2018, Bali, Indonesia.

(C) 2018 Association for Computing Machinery.

ACM ISBN 978-1-4503-6577-2/18/11 ..\$15.00

DOI: https://doi.org/10.1145/3291078.3291094 a light reading difficulty [1]. Of course, there are pupils with a heavy reading difficulty. The pupils with a heavy reading difficulty attend special support education classes or schools. In primary school years, girls show about two years progress than boys in their development. This difference makes it difficult to teach boys and girls in a same class [2].

To help a pupil, an ICT device must understand the activity of a pupil precisely. A human teacher can observe and understand not only the activity but also the inner state of a pupil. However, it need a huge computation power and a huge measuring system. In this paper, we will propose and implement the method to understand the activity precisely with the feasible ICT devices in a near future. The understanding of an activity is a start point of understanding of the inner state of a pupil.

Text reading prosody and reading comprehension have relations with each other [3]. Teachers observe a pupil to read aloud a text, and understand the ability of the pupil about text reading prosody. With some questions or tests, teachers estimate the reading comprehension of the pupils about the text. For understanding the features of a pupil, teachers need to know the abilities about text reading prosody and reading comprehension.

Japanese texts include many kinds of letters: Hiragana, Katakana, and Kanji. Therefore, reading Japanese texts may have many types of difficulties. We have proposed the system to observe reading activities using face images and read aloud voices [4]. The system can observe the activities about reading aloud, and generate an objective and quantative report about text reading aloud. However, the system cannot measure the precise gazing positions in the reading activities. Recently, we can use cheap and easy to use eye gazing detection devices. With the device, precise gazing detection is possible [5].

This paper proposes a method to make subjective observations of pupils about their reading aloud and problem solving activities with eye gazing detection. The observations are objective and quantative. The knowledge acquired from the observations are easy to generalize. This paper shows the method, the implementation, and the observation results. With the observations, teachers have many hints to understand the text reading prosody and reading comprehension.

First, the activities observed are discussed in the next section. Then, the reading activity and problem solving observing system is proposed. Next, the measurements' results are discussed. And last, we conclude this work.

\section{Read Aloud and Problem Solving Activities}

With silent reading, we have no information about the reading activities. In Japanese primary schools, read aloud activities are common. With the read aloud activities, teachers can estimate the ability of a pupil. Therefore, we focus on the read aloud activities. 
Observing read aloud activities, teachers estimate the fluency of text reading prosody easily. However, there is no information about their understandings of a text. Some pupils can read a text aloud fluently without the understanding of the text. Teachers want to find that kinds of pupils.

\subsection{Japanese Texts}

First, the structure of Japanese texts is described. Japanese texts include mainly three types of characters. Two types of characters are Hiragana and Katakana. They are phonogram as alphabet. The other is Kanji. Kanji is ideogram. There is no word spacing in Japanese texts. Adult Japanese can easily recognize word chunks with the help of boundary between a Kanji character and Hiragana character. A sequence of Katakana character makes one word that represents the phonetic representation of a foreign word and a sound that is not a word.

Japanese sentence ends by a punctuation mark. We can easily find a sentence in a sequence of characters. In a sentence, we can find a word chunk starting from a Kanji character and ending at the last Hiragana character in a sequence of Hiragana characters. There may be a word chunk only including Hiragana character. In the case, we have some difficulty to find a ward chunk.

\subsection{Change of Japanese Text in Primary School Ages}

In Japanese primary schools, pupils start to learn Japanese characters. In Japan, many infants learn Hiragana before primary school ages. However, a primary school is the first step of compulsory education in Japan.

In six years of a primary school, pupils learn Hiragana, Katakana, and Kanji characters. In Japan, if a pupil shows two years' delay of reading ability, the pupil is regarded as to have a reading difficulty. Some Japanese normal public primary schools have about $20 \%$ of pupils with a light reading difficulty. Of course, some pupils have a heavy reading difficulty. The pupils with a heavy reading difficulty attend special support education classes or schools.

Teachers want to help pupils with reading difficulties. However, it is difficult to find pupils with light reading difficulties in the first and second year in a primary school. If we can understand the precise reading activities, we can find a tiny sign of reading difficulties in very first stage. Teachers can help the pupils in very first stage of reading difficulties. The fast guidance may prevent the increase of reading difficulties. In many cases, a fast guidance is more effective than a late guidance.

In the first year of a primary school, only 80 Kanji characters are learned. Therefore, the text for a pupil at the start of second year only includes about 80 Kanji at most. Texts of the first year have word spacing. In a second year, texts have no word spacing as normal Japanese texts. At this stage, some pupils show reading difficulty about recognizing word chunks in a sentence. However, they can read the sentence as written by Hiragana and small number of Kanji. Their reading aloud voice has features that can be detected by experienced teachers. However, pupils of the second year cannot show two years delay from normal pupils. Therefore, it is difficult to find pupils that need some special help about reading.

In elder pupils, there is a problem about Kanji. Some pupils do not remember enough number of Kanji. Some pupils do not remember the phenomes representing the Kanji. In the case, a teacher easily finds the problem. However, there needs long time for checking all pupils in a class.
In a third year of a primary school, pupils show their abilities about reading apparently. Two years delay is apparent in this stage. Therefore, the third year of a primary school is proper timing to measure their abilities about readings.

\subsection{Word Chunk}

In Japanese texts, most of word chunks form the sequence of characters starting from Kanji, and ending to Hiragana. Of cause, in a very first year in primary school life, almost all word chunk is formed only by Hiragana. In the texts, a word chunk is separated from other chunks with a space to help to recognize word chunks.

Our Japanese text presentation sub-system presents a text with three levels of masking and highlighting [6]. With the highlighting, a user can easily find a word chunk.

The standard length of a highlighted part expands with the development of reading ability. In the long highlighted part, a pupil finds basic word chunks and recognize the relations among word chunks. Elder pupils may have a problem about this function.

In the text for elder pupils, there are many Kanji characters. Therefore, it is easy to find a basic word chunks in a sentence. However, in a long highlighted part, there are complex relations among word chunks.

In the third year of a primary school, pupils are expected to read a sentence by a sentence. Therefore, our Japanese text presentation sub-system moves the highlighted part a sentence by a sentence.

\subsection{Text}

For every years of primary schools, the text read by a subject must be prepared. However, our first subjects groups are third year of a primary school. The third year of a primary school is the first year when the reading difficulties are manifested. Therefore, the text fit for the pupils of the third year of primary schools is prepared.

The text read must not include the Kanji that is not learned before the third year of a primary school. The text includes both Hiragana and Katakana. It also includes proper Kanji. The text used in our experiments is shown in Table I. In Table I, Japanese sentences are in the left column. The meanings are shown in the right column.

\subsection{Problems}

In the proposed method, a subject answers some problems to measure the degree of understanding of the texts. The method propose five easy questions about the text read. Table II shows the five questions and their choices in English. About questions 1, 2, 3 , and 5, correct choices are described apparently in the text read. About question 4, the proper choice is not described apparently in the text read. A subject must estimate the season.

In the problem solving stage, the texts to read aloud is displayed on the left half of a display, and a question and choices of answers are displayed on the right half.

\section{Method to Observe Reading and Problem Solving Activities}

\subsection{Subjects}

In Japan, the reading difficulties manifest at the third year of a primary school. Pupils start to learn reading at the first year of a primary school. First, they learn Hiragana. At the third year of a primary school, pupils are expected to be able to read some simple texts that include Hiragana, Katakana and Kanji. This paper selects pupils in the third year of primary schools at our very first step. 


\subsection{Observing System Over-View}

Our observation system for reading and problem solving activities is based on the Japanese text presentation system for the pupils with reading difficulties [6]. Figure 1 shows the overall structure of the proposed observation system. A user looks at a display and shows his intention to go to next sentence with key-input. User's activity handing part controls the text presentation and question and choices presentation, and it records the precise activities of a user. In this paper's implementation, the recorded activities are key-inputs. Eyes' movements are recorded though out a trial with precise time. Text presentation sub-system displays the sentence read by the user is highlighted. With a proper key-input, the highlighted part moves to the next sentence.

\subsection{Texts and Problems}

The text is 252 characters and nine sentences. The first sentence means "Start". And, the last sentence means "End". The text used in our system is shows in Table I. Table I shows English in the second column. Figure 2 shows the text presentation on a display. On a read aloud stage, one sentence by one sentence is highlighted. In question solving stage, the right area of a display shows the question and choice box. Figure 3 shows an example of question and choice box. A text read aloud is displayed on the left area. A subject can read the text at every time in question answering stage.

\subsection{Trial}

One trial is constructed from three stages. The first stage is a calibration of eyes gazing measuring system. The second stage is

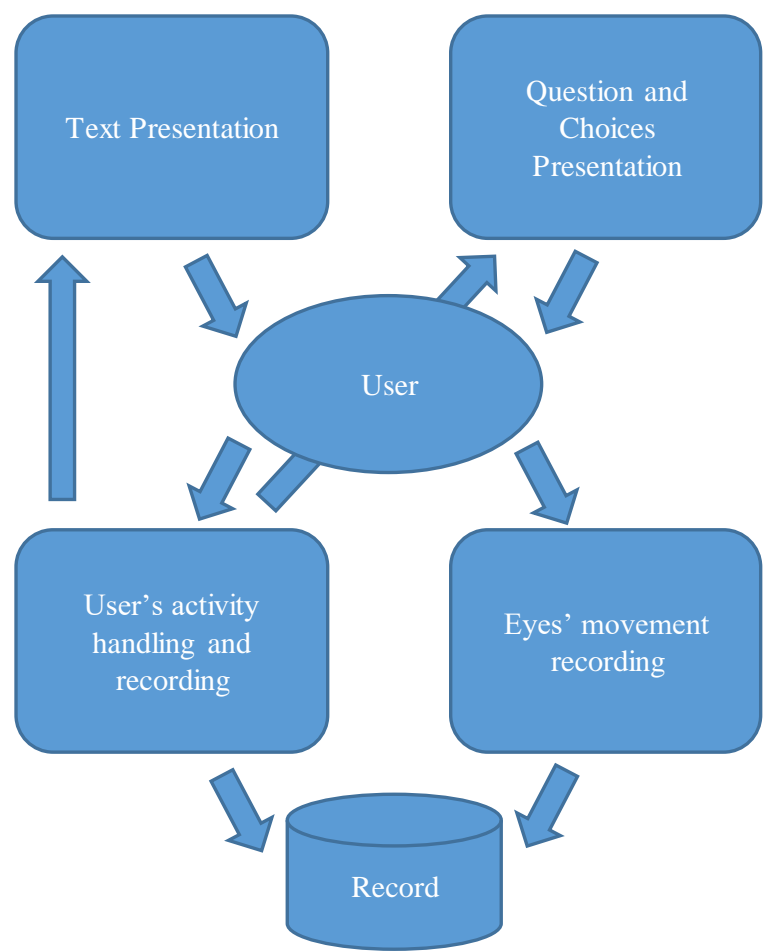

Figure 1. Outline of the Proposed System.
Table 1. Sentences Read

\begin{tabular}{|c|c|}
\hline Japanese & English \\
\hline はじめ & Start. \\
\hline $\begin{array}{l}\text { せんしゅうの土曜日、 } \\
\text { 家の近くの公園で姉と妹 } \\
\text { といっしょに遊びまし } \\
\text { た。 }\end{array}$ & $\begin{array}{l}\text { On last Saturday, I played } \\
\text { with my older sister and } \\
\text { sister at a park near my } \\
\text { house. }\end{array}$ \\
\hline $\begin{array}{l}\text { さいしょは、どんぐり } \\
\text { をひろったり、くりをあ } \\
\text { つめたりしました。 }\end{array}$ & $\begin{array}{l}\text { First, I picked up acorns } \\
\text { and garnished chestnuts. }\end{array}$ \\
\hline $\begin{array}{l}\text { わたしは } 6 \text { こで姉は } 10 \\
\text { こ、妹は } 3 \text { こでした。 }\end{array}$ & $\begin{array}{l}\text { I had } 6 \text {, my older sister } \\
\text { had } 10 \text {, and my sister had } 3 \text {. }\end{array}$ \\
\hline $\begin{array}{l}\text { つぎに、草むらに行っ } \\
\text { て虫さがしをしました。 }\end{array}$ & $\begin{array}{l}\text { Next, we went to the grass } \\
\text { to find insects. }\end{array}$ \\
\hline $\begin{array}{l}\text { こおろぎが「リーン、 } \\
\text { リーン、リーン」と鳴く } \\
\text { 声がしたのでそうっと行 } \\
\text { ってみると、いろいろな } \\
\text { しゅいの鳴き声が聞こ } \\
\text { えてきました。 }\end{array}$ & $\begin{array}{l}\text { After we heard a voice that } \\
\text { crickets cried "lean, lean, } \\
\text { lean", I went there silently, } \\
\text { and I heard a variety of } \\
\text { squealing sounds. }\end{array}$ \\
\hline $\begin{array}{l}\text { 「チンチロリン、チン } \\
\text { チロリン」という鳴き声 } \\
\text { が聞こえてくると、妹が } \\
\text { 「まつむしかなあ。」と } \\
\text { ささやきました。 }\end{array}$ & $\begin{array}{l}\text { When I heard a chirping } \\
\text { "Chinchirorin, Chinchirorin", } \\
\text { my sister whispered, "Is a } \\
\text { Matsumushi?" } \\
\text { ('Chinchirorin' is a sound } \\
\text { representation. 'Matsumushi' } \\
\text { is a name of an insect.) }\end{array}$ \\
\hline $\begin{array}{l}\text { すると、姉が「あれ } \\
\text { は、すずむしだよ。」と } \\
\text { 言いました。 }\end{array}$ & $\begin{array}{l}\text { Then, older sister said, } \\
\text { "That is a swoon." }\end{array}$ \\
\hline おおり。 & End. \\
\hline
\end{tabular}

Table 2. Questions and Choices

\begin{tabular}{|c|l|l|}
\hline ID & Question & Choices \\
\hline 1 & $\begin{array}{l}\text { Where do they } \\
\text { play? }\end{array}$ & $\begin{array}{l}\text { Park near the home. } \\
\text { Park far from the home. } \\
\text { Park near the school. }\end{array}$ \\
\hline 2 & $\begin{array}{l}\text { How many people } \\
\text { go to play? }\end{array}$ & $\begin{array}{l}\text { One person. } \\
\text { Two person. } \\
\text { Three person. }\end{array}$ \\
\hline 3 & $\begin{array}{l}\text { Who collects the } \\
\text { most acorn? }\end{array}$ & $\begin{array}{l}\text { Writer. } \\
\text { Elder sister. } \\
\text { Younger sister. }\end{array}$ \\
\hline 4 & $\begin{array}{l}\text { What season do } \\
\text { the text describe? }\end{array}$ & $\begin{array}{l}\text { Spring. } \\
\text { Summer. } \\
\text { Autumn. }\end{array}$ \\
\hline 5 & $\begin{array}{l}\text { How does a } \\
\text { cricket sound? }\end{array}$ & $\begin{array}{l}\text { "ri-n, ri-n, ri-n" rin, rin" } \\
\text { "chinchirorin, chinchirorin" }\end{array}$ \\
\hline
\end{tabular}


a practice to familiarize with the system operations. In this stage, a subject read a short text, and it answers a few easy questions. In the third stage, a subject read a proper text, and it answers the five questions. In a trial, an assistant guides a subject about the operations.

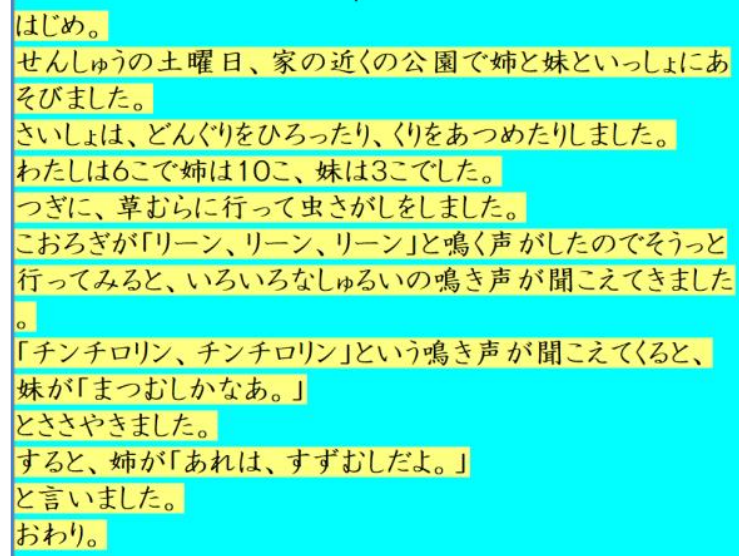

Figure 2. Text for the Third Year Pupils of Japanese Primary School
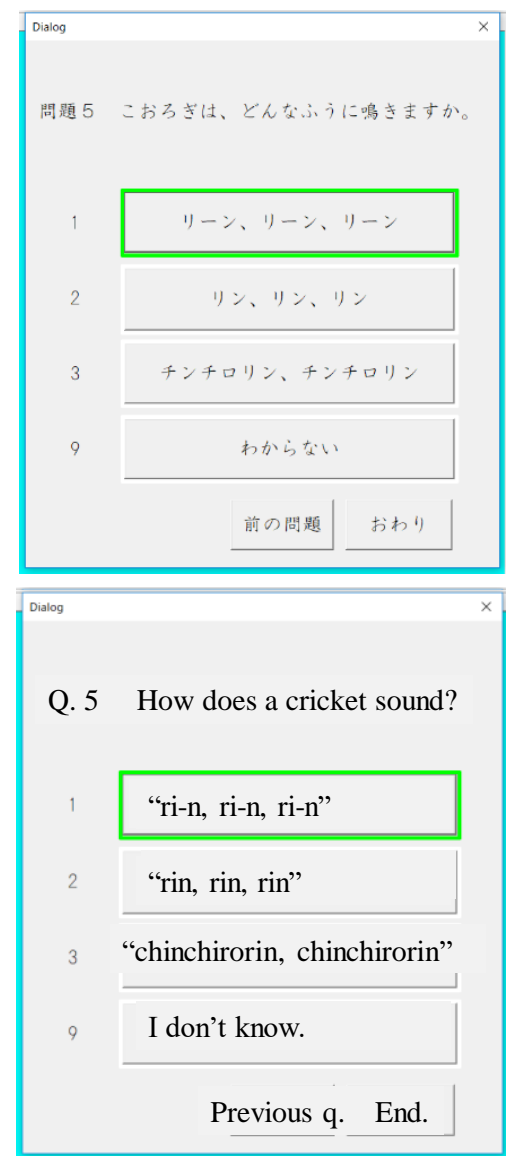

Figure 3. Example of Question Answering Box and its English Version

\subsection{Implementation of the observation system}

Our proposed method is implemented using notebook PC and Tobii EyeX [7]. The displayed question and response box is shown in Figure 3. The upper box is an original Japanese version. The lower one is an English version. On the top of the box, a question is shown. Under the question, three choices of suggested answers and impossible to answer are shown. A subject can select a choice using a mouse or a keyboard.

In reading aloud process, a display shows only the text read as Figure 4. A sentence read aloud is highlighted. In the right area of a display, no texts are shown.

In problem solving stage, a display shows the text and the question and answering box as Figure 5. A subject can refer the text to search the answer of a question.

\subsection{Trial}

One trail is constructed from three stages. The first stage is a calibration of a gaze detection device. This stage needs about three minutes to complete. The second stage is a practice reading aloud and problem solving. In this stage, a subject learns the key operations on reading aloud and problem solving with small text and a sample problem under the guidance of a teacher. In the last stage, a subject carries out read a text aloud and problem solving by itself.

\section{Experimental Results}

The proposed system makes many types of reports based on the objective and quantative observation. In the following, each report type is discussed.

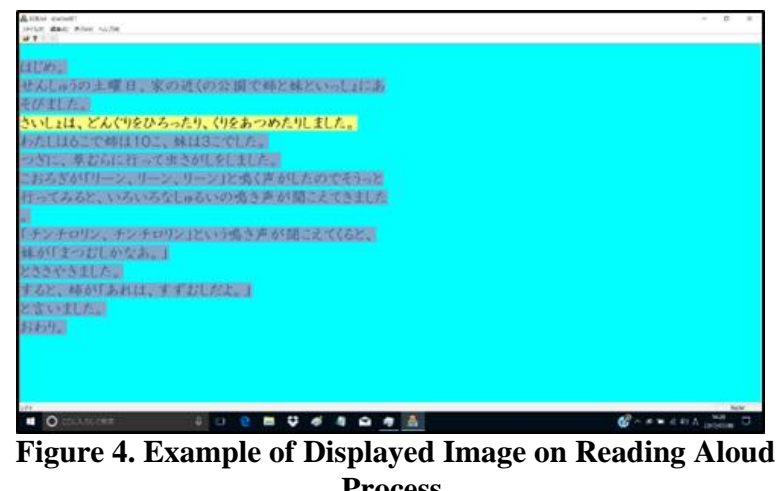
Process

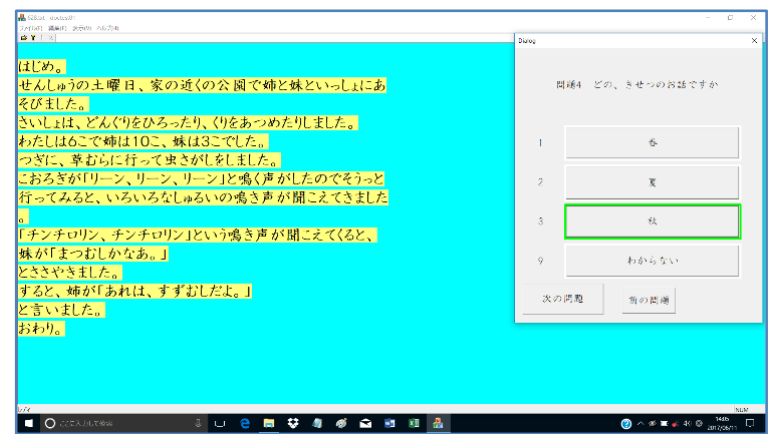

Figure 5. Example of Displayed Image on Problem Solving Stage

\subsection{Observation Experiments}

Subjects are all pupils in the third year of Japanese primary schools. The total number of subject is over 200. However, some pupils use glasses. With glasses, a gaze detection device cannot measure the gaze point with proper accuracy. The total number of effective observations is 154 . From the observation, the normal range of parameters in the following are decided. 


\subsection{Reading Time}

The proposed system records the precise time of user's key operation. With the recorded key operations, the reading time of each sentence is measured. From the reading time, we can estimated the reading activity type of a subject.

Figure 6 shows the display image that shows the relation between a sentence length and a reading time of the sentence. In the left side, some parameters about the diagram are shown. From the diagram, the difficulties of a subject is estimated. The solid line shows the normal reading time of the subject. The normal reading time is estimated removing the outlier data from all measurements.
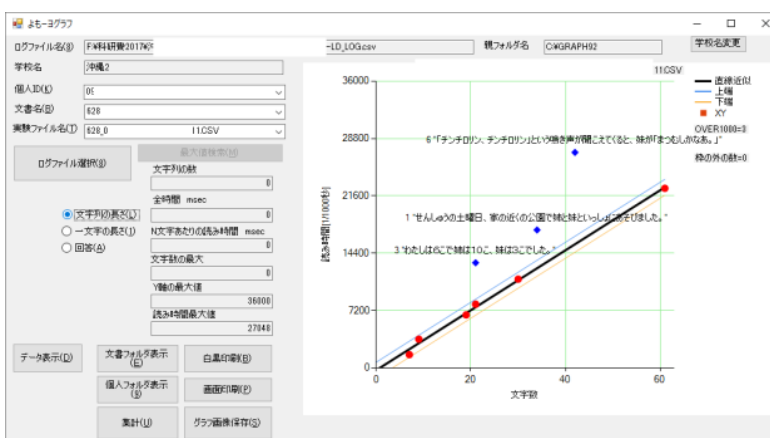

Figure 6. Example of Displayed Image of Reading Time Report

Figure 7 shows the diagram largely. The horizontal axis is the number of character in a sentence. The vertical axis is the consumption time at the sentence in millisecond. In Figure 7, the outlier sentences are shown with blue diamond marks. A subject has some difficulties to read the sentences. Teachers easily find the sentences that show some difficulties.

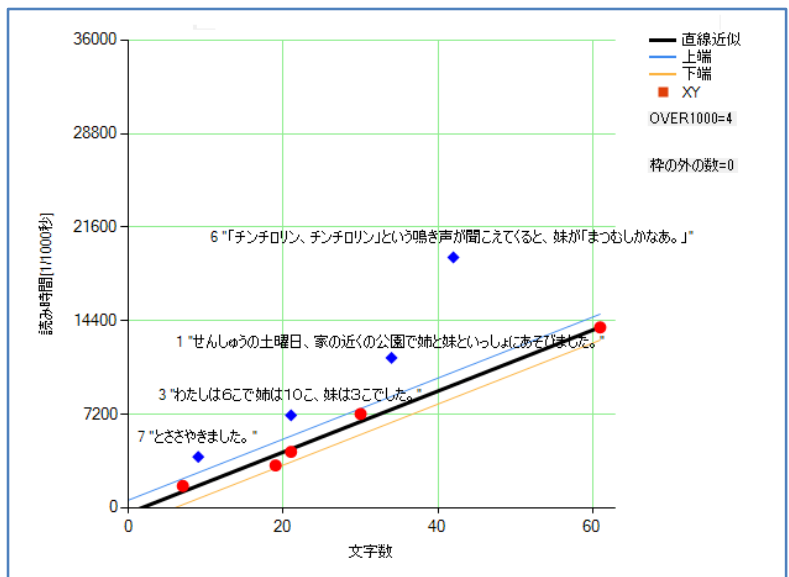

Figure 7. The Relation Between Reading Time and Sentence Length

Figure 8 shows the relation between a sentence length and a reading speed of the sentence. From the diagram, other types of reading difficulties are estimated.

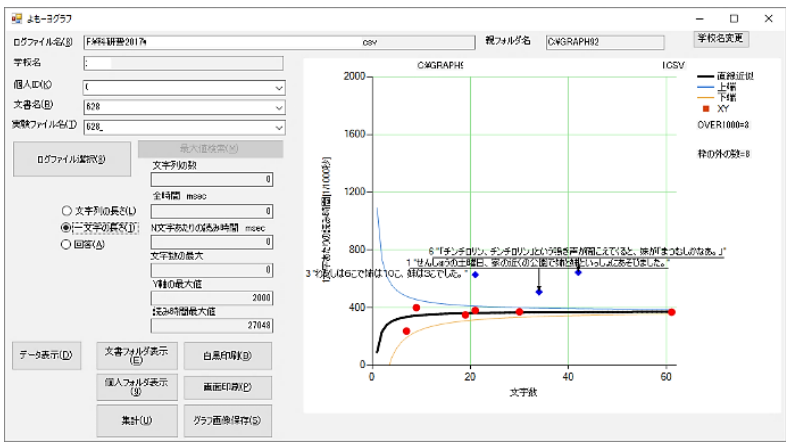

Figure 8. Example of a Displayed Image of Reading Speed Report

\subsection{Question answering time}

In the question answering stage, the time to answer each question is measured. Figure 9 is an example of displayed image of question answering report. Figure 10 shows the diagram largely.

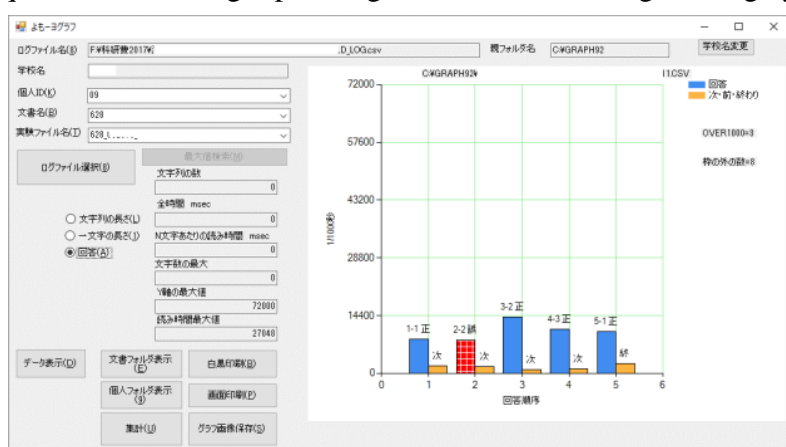

Figure 9. Example of a Displayed Image of Answering Time Report

In the diagram, answering time of each question is shown. At each question, a tuple of bars are shown. The left bar shows the time to select an answer. The right bar does the time to proceed to the next question. When an answer is correct, a left bar is blue. Otherwise, the bar is red. In Figure 10, the subject consumed much time to answer the question 4 , and selected a wrong answer.

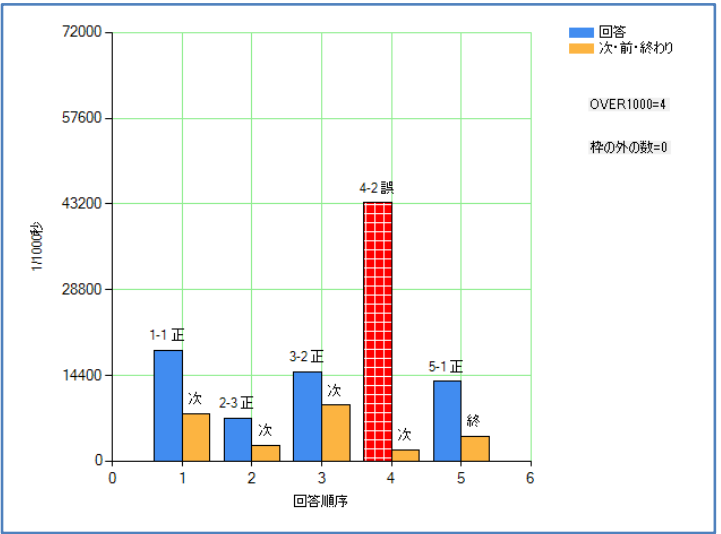

Figure 10. Question Answering Time Diagram

Figure 11 shows other example. The subject of Figure 11 selected all correct answers, and consumed less time than the subject of Figure 10. With the diagrams, teachers estimate difficulties to understand the text easily and apparently. 


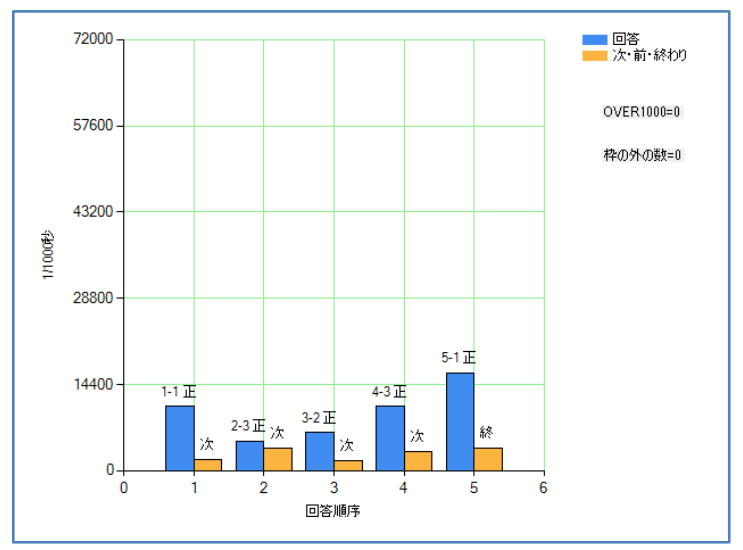

Figure 11. Question Answering Time Diagram

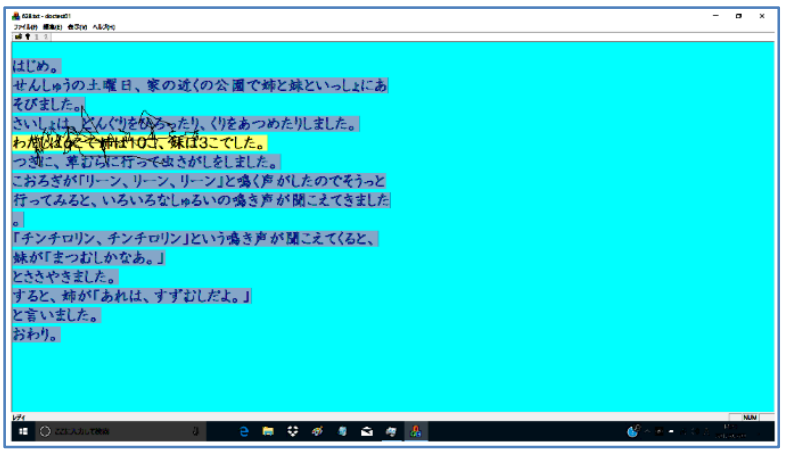

Figure 12. Example of the Movement of Eye Gazing in a Read Aloud Stage

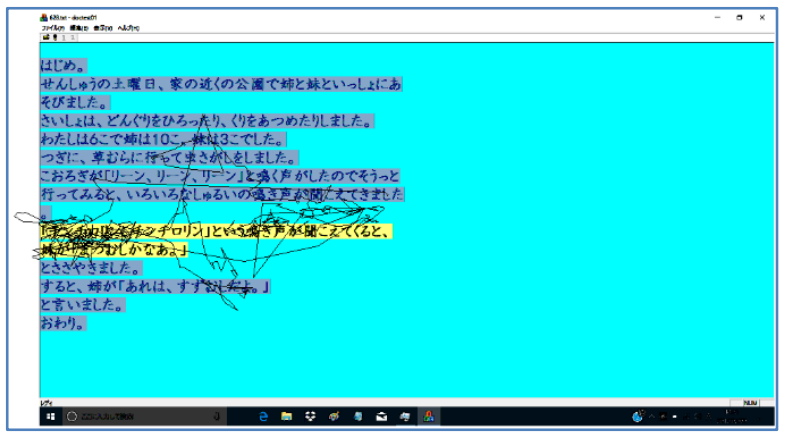

Figure 13. Other Example of the Movement of Eye Gazing in a Read Aloud Stage

\subsection{Eye Gazing in Reading Aloud Stage}

At each sentence, the proposed system make the tracing of eye gazing. Figure 12 is an example of the tracing of eye gazing. With this tracing, the reading process of a subject is estimated.

Figure 13 shows other example. In Figure 13, the gazing points are distributed other sentences. The subject of Figure 13 may have some problem about his eye movements. As this, these eye gazing diagrams show the problems about eye movements clearly.

\subsection{Eye Gazing in Question Answering Stage}

At each question, the proposed system make the tracing of eye gazing. Figure 14 and 15 show examples of the tracing of eye gazing of a question and an answering stage. With this tracing, the degree of understanding about the text and the activity to search an answer of the question are estimated. This subject did not understand the text well.
The subject of Figure 14 searched the answer through whole text. This subject is estimated not to understand the text well in reading aloud stage. The subject of Figure 15 searched only proper sentence only. This subject understood the text well in reading aloud stage, and confirmed his understanding. This eye gazing report helps teachers to understand the activities in question answering stage well.

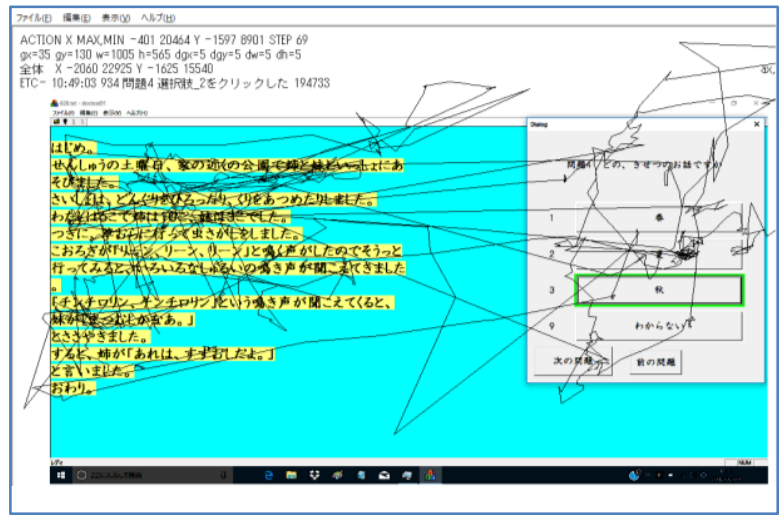

Figure 14. Example of The Movement of Eye Gazing Points in A Question Answering Stage

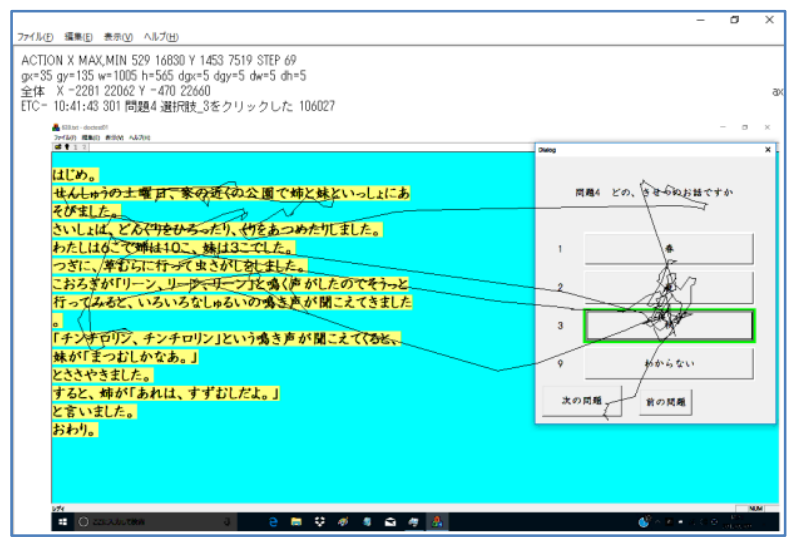

Figure 15. Example of The Movement of Eye Gazing Points in A Question Answering Stage

\section{CONCLUSION}

This paper proposes the objective and quantative observation system for reading aloud and question answering activities with eye gazing movement. The proposed system enables to make objective and quantative observations of reading aloud and question answering activities of a subject. Moreover, the proposed system makes reports of reading aloud activities and question answering activities based on the objective and quantative observations. These reports helps teachers to estimate the precise activities of a subject about reading and understanding texts. Teachers can estimate the type of reading activity and difficulties of a subject from the reports.

The proposed system generates many reports for one subject. The amount of reports for a whole pupil in a class is too large to be used by a teacher. Therefore, our next step is to append the proposed system a function to estimate the type of reading activity and difficulties of each subject from the objective and quantative observations.

\section{ACKNOWLEDGMENTS}

This work is supported by JSPS KAKENHI 16K04818 and $16 \mathrm{~K} 01057$. 


\section{REFERENCES}

[1] Yaguchi, Y., Kotaka, S., and Kajii, N. 2015. Characteristics of verbal abilities of children with peripheral developmental dyslexia. The Science of Reading, 57, 3-4, (Oct. 2015), 47-54.

[2] Aoki, K., Fukuda, N., Hotta, H. 2017. Gender Difference of Developments of Motor Control Function in Primary School Ages with Visual Synchronization Task of Hands' Movement. 2017. Inter. Journal of Social Science and Humanity, 7, 5, (May 2017), 269-273.

[3] Veenendaal, N. J., Margriet A. G., and Verhoeven, L. 2016. Bidirectional relations between text reading prosody and reading comprehension in the upper primary school grades: A longitudinal perspective. Scientific Studies of Reading, 20, 3 , (2016), 189-202.

$\mathrm{DOI}=$ https://doi.org/10.1080/10888438.2015.1128939.

[4] Aoki, K., Tashiro, S., and Aoki S. 2017. PRECISE ESTIMATION OF READING ACTIVITIES WITH FACE
IMAGE AND READ ALOUD VOICE. In Proceedings of the International Conference on Computer Supported Education 2017 (Porto, Portugal, April 21-23, 2017) 1, 315322.

[5] Rivas-Lalaleo, D., Luna, V., Alveriz, M., Andaluz, V., Quevedo, W., Santana, A., Vayas, G., Navas, M., and Huerta, M. 2017. System of Evaluation for Reading Based on Eye Tracking. SETE 2017, LNCS 10676, 234-241, 2017.

[6] Aoki, K., Murayama, S., and Harada, K. 2014. Automatic Objective Assessments of Japanese Reading Difficulty with the Operation Records on Japanese Text Presentation System. In Proceedings of 6th International Conference on Computer Supported Education (Barcelona, Spain, April 2014, 2, 139146.

[7] https://help.tobii.com/hc/en-us/articles/212818309Specifications-for-EyeX retrieved 2018-10-06. 